\title{
The phosphate transporter NaPi-IIa determines the rapid renal adaptation to dietary phosphate intake in mouse irrespective of persistently high FGF23 levels
}

\author{
Bourgeois, Soline ; Capuano, Paola ; Stange, Gerti ; Mühlemann, Reto ; Murer, Heini ; Biber, Jürg ;
} Wagner, Carsten A

\begin{abstract}
Renal reabsorption of inorganic phosphate $(\mathrm{Pi})$ is mediated by the phosphate transporters NaPi-IIa, NaPi-IIc, and Pit-2 in the proximal tubule brush border membrane (BBM). Dietary Pi intake regulates these transporters; however, the contribution of the specific isoforms to the rapid and slow phase is not fully clarified. Moreover, the regulation of PTH and FGF23, two major phosphaturic hormones, during the adaptive phase has not been correlated. C57/BL6 and NaPi-IIa(-/-) mice received 5 days either $1.2 \%$ (HPD) or $0.1 \%$ (LPD) Pi-containing diets. Thereafter, some mice were acutely switched to LPD or HPD. Plasma Pi concentrations were similar under chronic diets, but lower when mice were acutely switched to LPD. Urinary Pi excretion was similar in C57/BL6 and NaPi-IIa(-/-) mice under HPD. During chronic LPD, NaPi-IIa(-/-) mice lost phosphate in urine compensated by higher intestinal Pi absorption. During the acute HPD-to-LPD switch, NaPi-IIa(-/-) mice exhibited a delayed decrease in urinary Pi excretion. PTH was acutely regulated by low dietary Pi intake. FGF23 did not respond to low Pi intake within $8 \mathrm{~h}$ whereas the phospho-adaptator protein FRS2 necessary for FGF-receptor cell signaling was downregulated. BBM Pi transport activity and NaPi-IIa but not NaPi-IIc and Pit-2 abundance acutely adapted to diets in C57/BL6 mice. In NaPi-IIa(-/-), Pi transport activity was low and did not adapt. Thus, NaPi-IIa mediates the fast adaptation to Pi intake and is upregulated during the adaptation to low Pi despite persistently high FGF23 levels. The sensitivity to FGF23 may be regulated by adapting FRS2 abundance and phosphorylation.
\end{abstract}

DOI: https://doi.org/10.1007/s00424-013-1298-9

Posted at the Zurich Open Repository and Archive, University of Zurich

ZORA URL: https://doi.org/10.5167/uzh-85188

Journal Article

Accepted Version

Originally published at:

Bourgeois, Soline; Capuano, Paola; Stange, Gerti; Mühlemann, Reto; Murer, Heini; Biber, Jürg; Wagner, Carsten A (2013). The phosphate transporter NaPi-IIa determines the rapid renal adaptation to dietary phosphate intake in mouse irrespective of persistently high FGF23 levels. Pflügers Archiv : European Journal of Physiology, 465(11):1557-1572.

DOI: https://doi.org/10.1007/s00424-013-1298-9 
The phosphate transporter NaPi-lla determines the rapid renal adaptation to dietary phosphate intake in mouse irrespective of persistently high FGF23 levels

Soline Bourgeois, Paola Capuano, Gerti Stange, Reto Mühlemann, Heini Murer, Jürg Biber, Carsten A. Wagner

Institute of Physiology and Zurich Center for Integrative Human Physiology (ZIHP), University of Zürich, Switzerland

Corresponding author

Carsten A Wagner

Institute of Physiology

University of Zurich

Winterthurerstrasse 190

$\mathrm{CH}-8057$ Zurich

Switzerland

Phone: +41-44-63 55023

Fax: +41-44-63 56814

Email:Wagnerca@access.uzh.ch 


\section{ABSTRACT}

Renal reabsorption of inorganic phosphate $(\mathrm{Pi})$ is mediated by the phosphate transporters, NaPi-Ila, NaPi-llc, and Pit-2 in the proximal tubule brush border membrane $(\mathrm{BBM})$. Dietary $\mathrm{Pi}$ intake regulates these transporters, however, the contribution of the specific isoforms to the rapid and slow phase are not fully clarified. Moreover, the regulation of PTH and FGF23, two major phosphaturic hormones, during the adaptive phase has not been correlated. C57/BL6 and NaPi-Ila ${ }^{-/-}$mice received 5 days either $1.2 \%$ (HPD) or $0.1 \%$ (LPD) Pi containing diets. Thereafter, some mice were acutely switched to LPD or HPD. Plasma Pi concentrations were similar under chronic diets, but lower when mice were acutely switched to LPD. Urinary Pi excretion was similar in C57/BL6 and $\mathrm{NaPi}^{-1 / a^{-/}}$mice under HPD. During chronic LPD, NaPi-lla/- mice lost phosphate in urine compensated by higher intestinal $\mathrm{Pi}$ absorption. During the acute HPD-to-LPD switch, $\mathrm{NaPi}-\mathrm{Ila}^{-/-}$mice exhibited a delayed decrease in urinary $\mathrm{Pi}$ excretion. PTH was acutely regulated by low dietary Pi intake. FGF23 did not respond to low Pi intake within 8 hours whereas the phosphoadaptator protein FRS2 $\alpha$ necessary for FGF-receptor cell signaling was downregulated. BBM Pi transport activity and NaPi-lla but not NaPi-llc and Pit-2 abundance acutely adapted to diets in C57/BL6 mice. In NaPi-lla ${ }^{-/-} \mathrm{Pi}$ transport activity was low and did not adapt. Thus, NaPi-lla mediates the fast adaptation to Pi intake and is upregulated during the adaptation to low Pi despite persistently high FGF23 levels. The sensitivity to FGF23 may be regulated by adapting FRS2 $\alpha$ abundance and phosphorylation. 


\section{INTRODUCTION}

In mammals, including humans, plasma concentration of inorganic Phosphate (Pi) is determined by intestinal intake, excretion via feces, distribution between bone and soft tissues, and renal excretion and reabsorption, respectively (for review: [12, $38,40])$. The latter mechanism is of major importance for whole body Pi homeostasis and therefore tightly controlled. Reabsorption of filtered $\mathrm{Pi}$ by the kidneys occurs mostly in the proximal tubule $[12,38,40]$. In the brush border membrane (BBM), three transporters have been identified so far: NaPi-Ila (SLC34A1) and NaPi-Ilc (SLC34A3), two transporters from the NaPi/SLC34 family and more recently Pit-2 (SLC20A2) [12, $38,49,59]$. However, these transporters have distinct transport properties with respect to ion coupling, preferred species of phosphate, voltage sensitivity and $\mathrm{pH}$ dependence $[12,38,46,49,60]$. NaPi-Ila and Pit-2 mediate the electrogenic transport of inorganic phosphate coupled to three and two sodium ions, respectively, whereas NaPi-Ilc transports inorganic phosphate together with two sodium ions in an electroneutral fashion. Moreover, $\mathrm{NaPi}$-lla and $\mathrm{NaPi}-\mathrm{Ilc}$ prefer divalent inorganic phosphate $\left(\mathrm{HPO}_{4}{ }^{2-}\right)$. In contrast, Pit transporters preferentially transport monovalent phosphate $\left(\mathrm{H}_{2} \mathrm{PO}_{4}{ }^{-}\right)[12,38,46,60]$.

Renal phosphate reabsorption is regulated by many factors including parathyroid hormone (PTH), dopamine, dietary phosphate intake, glucocorticoids, vitamin $\mathrm{D}_{3}$, acid-base status, growth factors, insulin, sFRP4, and FGF23 [4-6, 11-12, $17,35,39,42,44]$. NaPi-lla abundance in the brush border membrane is controlled by parathyroid hormone, FGF23 and dietary Pi intake $[8,12,29]$. In rat, mouse, and rabbit, NaPi-Ila is upregulated by low $\mathrm{Pi}$ diet and decreased by high $\mathrm{Pi}$ intake both acutely and chronically $[16-17,29,57]$. This regulation occurs essentially by trafficking 
of the protein, lysosomal degradation, recruitment of newly synthesized transporters [5, 26, 29-30] and may also include transcriptional regulation [34]. Much less is known about the regulation of $\mathrm{NaPi}-$ Ilc being regulated also by PTH, FGF23, and Pi intake with a slower change in brush border membrane abundance upon high $\mathrm{Pi}$ intake or PTH application [8, 28, 43-44]. Similarly, Pit-2 is regulated by PTH and dietary Pi or potassium intake but no further regulators have been identified to date $[15,44,59]$.

The relative contribution of $\mathrm{NaPi}-\mathrm{Ila}$ to the adaptive response of the kidney to acute and chronic changes in dietary phosphate intake remains to be clarified. Therefore, we compared renal phosphate handling during acute and chronic adaptive changes in dietary phosphate intake between C57/BL6 mice and mice lacking NaPiIla. Our second aim was to correlate changes in renal phosphate handling in C57/BL6 mice with levels of the two major phosphaturic hormones PTH and FGF23 and their main cellular downstream effectors PTH receptor 1 and the FGF receptor adaptor protein FRS2 $\alpha$.

Our results demonstrate a major role of $\mathrm{NaPi}$-Ila during the acute phase of renal adaptation to low phosphate intake whereas during chronic low phosphate intake lack of NaPi-Ila is mostly compensated by enhanced intestinal phosphate absorption. PTH levels followed phosphate intake whereas FGF23 responded more slowly to switching from high to low phosphate intake and high FG23 levels persisted for more than 8 hours. At the cellular level, low phosphate intake correlated with a reduction in the abundance of FRS2 $\alpha$, the major adaptor protein mediating the downstream signaling from the FGF1 receptor. NaPi-lla membrane abundance increased during these 8 hours despite high FGF23. 


\section{METHODS}

\section{Animals}

All experiments were performed with 10 - 14 week-old C57BL/6J and homozygous NaPi-lla deficient $\left(\mathrm{Slc} 34 \mathrm{a}^{-/-}\right)$male mice bred in a pure C57/BL6 background [7]. The generation, breeding and genotyping of $\mathrm{NaPi}-\mathrm{Ila} \mathrm{KO}$ mice have been described previously [7]. All experiments were performed according to the Swiss Animal Welfare laws and approved by the local veterinary authority (Veterinäramt Zürich, autorisation $\left.n^{\circ} 32 / 2009\right)$.

\section{Metabolic studies}

Mice were kept in standard cages for the first 4 days (days 1-4) and adapted to metabolic cages (Tecniplast, Buguggiate, Italy) by placing them in metabolic cages during the day and in standard cages during the night. Days 5-9, mice were housed in metabolic cages. Mice received standard rodent chow $\left(0.8 \% \mathrm{P}_{\mathrm{i}}, 1.2 \% \mathrm{Ca}^{2+}\right)(\mathrm{Kliba}$ NAFAG, Kaiseraugst, Switzerland) during days 1-4 but were trained to receive food only during 4 hours in the morning (between 7 AM to $11 \mathrm{AM}$ ). On day 5, animals were subdivided into two experimental groups. The first group received $0.1 \% \mathrm{P}_{\mathrm{i}}$ and $1.0 \%$ $\mathrm{Ca}^{2+}$ diet and the second $1.2 \% \mathrm{P}_{\mathrm{i}}$ and $1.0 \% \mathrm{Ca}^{2+}$ diet (Kliba; NAFAG, Kaiseraugst, Switzerland). Both diets contained equal amounts of vitamin D (1000 IU/Kg). On day 7, 24 hrs urine and feces collections were performed in metabolic cages to assess chronic adaptation.

On day 9 , half of each group was switched for $4 \mathrm{hrs}$ in the morning to low or high Pi diets, respectively, and the following experimental groups were established: 1) chronic low $\mathrm{Pi}$ diet group (LPD) receiving only $0.1 \% \mathrm{Pi}$ diet; 2 ) acute high $\mathrm{Pi}$ diet (L/HPD): mice were fed $0.1 \% \mathrm{Pi}$ diet for 4 days and acutely switched to $1.1 \% \mathrm{Pi}$ diet 
for 4 hrs on the last day; 3) chronic high Pi diet group (HPD) receiving only $1.1 \% \mathrm{Pi}$ diet; 4) acute low Pi diet (H/LPD) mice were fed for 4 days $1.1 \%$ Pi diet and were acutely switched on the last day to $0.1 \% \mathrm{Pi}$ diet for $4 \mathrm{hrs}$. Some mice received also only high or low Pi diets for 5 days with access to food over 24 hrs to assess the effects of timed feeding on overall adaption. Mice were sacrificed on day 9 and urine, blood, and kidneys were collected for acute studies and stored at $-80^{\circ} \mathrm{C}$ for further analyses.

\section{Urine, plasma, and feces analysis}

$24 \mathrm{hrs}$ feces were solubilized overnight at $95^{\circ} \mathrm{C}$ in $2 \mathrm{ml}$ of $1.2 \mathrm{M}$ nitric acid in a luer lock glass tube. Volumes were equalized with water to $4 \mathrm{ml}$ in each sample and ions were measured in the supernatant. Plasma, urine and feces $\mathrm{P}_{\mathrm{i}}$ concentration was determined by the phosphomolybdate method [23] and urinary creatinine by a modified kinetic Jaffé colorimetric method [52]. PTH 1-84 and FGF23 plasma levels were measured with ELISA assays specific for mouse PTH 1-84 and mouse Cterminal FGF23 (Immunotopics, San Clemente, CA).

\section{RNA extraction, reverse transcription and semi-quantitative real-time PCR}

Kidneys were harvested and rapidly frozen in liquid nitrogen. Snap-frozen kidneys (five to seven kidneys for each condition) were homogenized in RLT-Buffer (Qiagen, Basel, Switzerland) supplemented with B-mercaptoethanol to a final concentration of $1 \%$. RNA extraction, reverse transcription, and semi-quantitative realtime PCR were performed as described previously [42].

\section{Brush border membrane vesicle preparation and phosphate uptake experiments}


BBMV were prepared from total frozen kidneys using the $\mathrm{Mg}^{2+}$ precipitation technique as described previously [13-14]. The phosphate transport rate into BBMV was measured in freshly prepared BBMV at $25^{\circ} \mathrm{C}$ in the presence of inward gradients of $100 \mathrm{mM} \mathrm{NaCl}$ or $100 \mathrm{mM} \mathrm{KCl}$ and $0.1 \mathrm{mM} \mathrm{K}$-phosphate. The substrate $P_{i}$ was made with $0.125 \mathrm{mM} \mathrm{K}_{2} \mathrm{HPO}_{4}$ and ${ }^{32} \mathrm{P}(1 \mu \mathrm{Ci} / \mathrm{ml})$ to give a final concentration $0.1 \mathrm{mM}$ close to the expected apparent $\mathrm{Km}_{\mathrm{Pi}}$ for $\mathrm{Na}^{+}$-dependent transport in renal BBMV. The stop solution contained $100 \mathrm{mM}$ Mannitol, $5 \mathrm{mM}$ Tris- $\mathrm{HCl} \mathrm{pH}$ 7.4, $150 \mathrm{mM} \mathrm{NaCl}, 5 \mathrm{mM} \mathrm{Pi}$. $\mathrm{Na}^{+}$-dependence was established by incubating BBMV in solutions in which $\mathrm{KCl}$ replaced $\mathrm{NaCl}$ equimolarly. Phosphate uptake was determined after $60 \mathrm{~s}$, representing initial linear conditions, and after $120 \mathrm{~min}$, to determine the equilibrium values. Total protein concentration was measured using the Bio-Rad Protein Assay kit, Bio-Rad, Hercules, CA, USA. Remaining BBMV were stored at $-80^{\circ} \mathrm{C}$ until further use.

\section{Immunoblotting}

Fifteen to twenty micrograms of renal brush border membrane proteins or fifty micrograms of kidney homogenates were solubilized in Laemmli loading buffer containing DTT (2 mM) and separated on $8 \%$ polyacrylamide gels. Coomassie bluestained polyacrylamide gels were used to control equality of protein loading for each series [45]. For immunoblotting, the proteins were transferred electrophoretically to polyvinylidene fluoride membranes (Immobilon-P, Millipore Corp., Bedford, MA, USA). After blocking with 5\% milk powder in Tris-buffered saline for $60 \mathrm{~min}$, the blots were incubated with the primary antibodies: rabbit polyclonal anti-NaPi-Ila $(1: 4,000)[19]$, rabbit polyclonal anti-NaPi-Ilc $(1: 5,000)$ [42], rabbit polyclonal anti-Pit-2 $(1: 3,000)$ (kind gift from V. Sorribas, University of Zaragossa, Spain) [59], rabbit polyclonal antiparathyroid hormone receptor $(1: 1,000)$ (Covance, NJ, USA), rabbit polyclonal antiphospho-FRS2 $\alpha(1: 2,000)$ (Cell Signaling, MAs, USA), mouse monoclonal anti-FRS2 $\alpha$ 
$(1: 1,500)$ (R\&D Systems, MI, USA), and mouse monoclonal anti $\beta$-actin 1:25,000 (Sigma Aldrich, Buchs, Switzerland) overnight at $4^{\circ} \mathrm{C}$. After washing, membranes were then incubated for one hrs at room temperature with secondary goat anti-rabbit antibodies 1:5,000 linked to alkaline phosphatase (Promega, Madison, WI, USA) or HRP 1:10,000 (Amersham Life Science, Little Chalfont Buckinghamshire, UK). The protein signal was detected with the appropriate substrates (Millipore Corp, Bedford, MA, USA) using the DIANA III-chemiluminescence detection system (Raytest, Straubenhardt, Germany). All images were analyzed using the software Advanced Image Data Analyser AIDA (Raytest, Straubenhardt, Germany).

\section{Immunohistochemistry}

Mouse kidneys were perfusion fixed through the right ventricule with a $4 \%$ paraformaldehyde fixative/PBS solution and the subsequent immunohistochemistry were performed as described previously [5]. Slices of fixed kidneys were frozen in liquid propane and cooled with liquid nitrogen. Serial sections, $5-\mu \mathrm{m}$ thick, were cut at $22^{\circ} \mathrm{C}$ on a cryomicrotome (Leica, Solms, Germany), mounted on superfrost slides, thawed, and kept in cold PBS until use. Before immunofluorescence staining, sections were pretreated with blocking solution (bovine serum albumin 1\% in PBS) for 60 min. After blocking, serial sections were incubated overnight at $4^{\circ} \mathrm{C}$ either with a rabbit antirat NaPi-Ila [19] diluted 1:1,000 or with an immunopurified rabbit anti-mouse NaPi-Ilc [42] diluted 1:1,500 or a rabbit anti-rat Pit-2 [59] diluted 1:300. All primary antibodies were diluted in PBS with 1\% bovine serum albumin. Sections were then rinsed three times with PBS and covered for $1 \mathrm{hrs}$ at $4^{\circ} \mathrm{C}$ with the secondary antibodies: Alexa Fluor 555 goat-anti-rabbit IgG (1:500, Invitrogen), FITC-phalloidin (1:100, Invitrogen ), and 4,6-diamidino-2-phenylindole (DAPI; Sigma, St Louis, MO), dilution 1:1,000). 
Finally, the sections were rinsed three times with PBS, coverslipped using Glycergel Mounting Medium (Dako AG, Baar, Schweiz).

\section{Statistical analysis}

Results are expressed as mean \pm SEM. All data were tested for significance using ANOVA and unpaired student's test where appropriate. Only values with $p<$ 0.05 were considered as significant. 


\section{RESULTS}

Adaption of plasma Pi concentration, urinary Pi excretion and intestinal Pi reabsorption during chronic low and high phosphate diets

Results from plasma Pi determinations in C57/BL6 and $\mathrm{NaPi}-\mathrm{Ila}^{-/-}$mice after 5 day chronic low or high phosphate diet are shown in table 1 and figure 1. Both mouse strains exhibited similar plasma Pi concentrations depending on diets; high plasma $\mathrm{Pi}$ concentrations during HPD $(2.42 \pm 0.20 \mathrm{mM}$ and $1.95 \pm 0.44 \mathrm{mM})$ and lower plasma Pi concentrations on LPD $(0.50 \pm 0.06 \mathrm{mM}$ and $0.32 \pm 0.09 \mathrm{mM})$. Nevertheless, after 4 days of chronic diets, C57/BL6 and NaPi-Ila ${ }^{-/}$mice had different 24 hrs Pi urinary excretion rates. $\mathrm{NaPi}-\mathrm{Ia}^{-/-}$mice excreted more $\mathrm{Pi}$ with the acute and chronic low $\mathrm{Pi}$ diets (figure 2, table 1). This urinary leak was partially compensated by an increase in intestinal Pi absorption during LPD (table 2, figure 3). We determined also total plasma calcium levels and found significantly elevated plasma calcium in the group of mice receiving a chronic low Pi diet (table 1). In the groups with acute changes of Pi intake, no significant difference could be detected.

\section{Plasma Pi concentration and urinary Pi excretion during acute switches in dietary Pi intake}

Plasma and urine Pi concentrations were determined 4 hrs after switching diets. In C57/BL6 mice, switching from high to low Pi diet decreased plasma Pi concentration by $55 \%$ whereas $\mathrm{NaPi}-\mathrm{Ila}^{-/}$mice drastically reduced their plasma $\mathrm{Pi}$ concentration by $83 \%$ (figure 1, table 1). In contrast, no significant difference between C57/BL6 and $\mathrm{NaPi}^{-I l a}{ }^{-/-}$was observed when mice were switched from low to high Pi intake.

$\mathrm{NaPi}-1 \mathrm{Il}{ }^{-/-}$mice excreted inappropriately high amounts of phosphate not only during chronic dietary treatments but also during the acute switch. C57/BL6 mice rapidly adapted their $\mathrm{Pi}$ excretion when switched from high to low Pi intake, whereas 
$\mathrm{NaPi}^{-1 I a-}{ }^{-/}$mice failed reducing their Pi excretion to the same level (89\% versus $59 \%$ in $\mathrm{NaPi}-\mathrm{Ila}^{-/-}$mice). This discrepancy was not observed to the same extent when mice were acutely adapted to high Pi diet (figure 2 , table 1).

\section{Phosphate transport, NaPi-lla, NaPi-Ilc, and Pit-2 expression and trafficking during chronic and acute changes in dietary phosphate}

In C57/BL6 mice, where NaPi-Ila, NaPi-Ilc and Pit-2 are all expressed, $\mathrm{Na}^{+}-$ dependent ${ }^{32} \mathrm{P}$ uptake into brush border membranes vesicles (BBMV) was enhanced with LPD as expected. $\mathrm{Na}^{+}$-dependent ${ }^{32} \mathrm{P}$ uptake was also acutely regulated following Pi intake (figure 4A). In BBMV from NaPi-Ila ${ }^{-/-}$mice uptake was significantly lower in all four groups and not altered by diet (figure 4B).

We performed real-time RT-PCR experiments on C57/BL6 tissue (figure 5). $\mathrm{NaPi}-\mathrm{Ila}$ and $\mathrm{NaPi}$-Ilc mRNAs abundance were modulated chronically and acutely only under LPD to HPD. In contrast, we could not detect any regulation at the mRNA level for Pit-2 (figure 5). Moreover, in NaPi-lla ${ }^{-/-}$tissue, no change in NaPi-llc or Pit-2 mRNA was observed whatever the diets (figure 5).

Next, we determined the abundance of NaPi-Ila, NaPi-Ilc and Pit-2 proteins in the brush border membrane from C57/BL6 kidneys after 4 hrs and 24 hrs feeding of high and low dietary phosphate. The expression of all three transporters was significantly increased in kidney BBM from mice fed 24 hrs with low phosphate (figure 6). However, when the mice were acutely challenged with $4 \mathrm{hrs}$ feeding dietary phosphate, only the abundance of $\mathrm{NaPi}$-lla was significantly modulated by acute dietary phosphate. NaPi-Ilc and Pit-2 expression remained unchanged (figure 7).

The subcellular distribution of NaPi-lla, NaPi-Ilc and Pit-2 proteins was further investigated by immunohistochemistry on kidney sections from C57/BL6 mice fed 4 hrs with the different regimens. As already demonstrated previously in rat kidney [48], 
$\mathrm{NaPi}-\mathrm{Ila}$ can be found both at the plasma membrane and in intracellular compartments during all diets, however, with different distribution along the nephron axis (data not shown). During HPD, NaPi-lla related staining was weak in the brush border membrane but rather diffusively expressed in the cytoplasm. Some intracellular organelles were highly stained that may represent the Golgi apparatus. In contrast, during LPD, NaPi-lla was highly expressed at the brush border membrane but was only weakly detected in the cytoplasm and remained visible in intracellular organelles. NaPi-Ilc and Pit-2 proteins were exclusively detected at the brush border membrane but their intensity of staining changed with dietary phosphate intake being low during HPD and high during LPD (figure 8).

\section{PTH and FGF23 change with different kinetics to dietary phosphate intake}

Plasma PTH and FGF23 are both modulated by dietary phosphate $[8,47]$. Here, we determined plasma PTH and FGF23 levels in C57/BL6 mice under the various dietary conditions in order to correlate hormone levels with urinary Pi excretion and renal expression of phosphate transporters. PTH followed dietary phosphate intake increasing with high phosphate and decreasing with low phosphate intake and these changes were achieved within the $4 \mathrm{hrs}$ after switching diets (figure 9 and table 3). In contrast, the abundance of the PTH receptor 1 in kidney BBM remained unaltered during the acute and chronic switches (figure 10). In contrast, FGF23 showed a tendency to be lower with chronic low $\mathrm{Pi}$ intake compared to chronic high $\mathrm{Pi}$ intake and responded only to the acute switch from low to high phosphate but not to the high to low switch (figure 9 and table 3). In order to test whether circulating FGF23 acted in the kidney, we examined the total amount of the FGF adaptor protein FRS2 $\alpha$ and its phosphorylated active form p-FRS2 $\alpha$. p-FRS2 $\alpha$ mediates the down-stream 
signals from the FGF1 receptor upon stimulation by the FGF23/klotho complex [27]. Total FRS2 $\alpha$ followed dietary phosphate intake increasing with a high phosphate diet and decreasing during a low phosphate diet. p-FRS2 $\alpha$ exhibited also changes during chronic switches but had a slower response than FRS2 $\alpha$ during the acute HPD to LPD switch and did not acutely adapt during the LPD to HPD switch (figure 10) suggesting reduced FGF23 signaling during acute low $\mathrm{Pi}$ intake despite elevated circulating FGF23.

\section{Time course of regulatory mechanisms involved in the acute HPD to LPD switch}

To better characterize the adaptive mechanisms involved in the acute HPD to LPD switch, we performed an additional time course experiment with four groups of WT mice adapted to high phosphate and acutely switched to low phosphate diet after 2, 4 and 8 hrs, respectively. Plasma PTH level was drastically reduced 2 hrs after switching to low phosphate while plasma FGF23 level remained unchanged for at least 8 hours (figure 11 and table 4 ). PTH receptor 1 exhibited no change while total $p$ FRS2 $\alpha$ and FRS2 $\alpha$ decreased after 2 hrs and 4 hrs, respectively of HPD to LPD switch (figure 12). Finally, NaPi-lla expression in the brush border of these animals gradually increased $4 \mathrm{hrs}$ after changing to low phosphate (figure 13) 


\section{DISCUSSION}

The acute and chronic effects of dietary phosphate on phosphate (Pi) transport in the proximal tubule have been studied in great details [12, 33, 38-39]. Taken together, these studies demonstrate that phosphate intake has a direct effect on kidney Pi transport and occurs acutely mainly by trafficking of transporters into or out of the brush border membrane and chronically also by transcriptional and translational mechanisms [12, 33, 37]. In the kidney, three transporters have been identified at the brush border membrane of proximal tubule cells, NaPi-lla, NaPi-llc, and Pit-2. In rodents, the modulation of their expression and function by dietary Pi had only been studied for NaPi-lla in some details but little is known about the relative contribution and fast adaption of NaPi-Ilc and Pit-2 [29, 43, 59]. Moreover, the correlation with the regulation of the phosphaturic hormones PTH and FGF23 during acute changes in phosphate intake has not been reported to date [8].

Here, we demonstrated, using C57/BL6 and NaPi-lla ${ }^{-/-}$mice that NaPi-lla is the main adaptive $\mathrm{NaPi}$ transporter required for acute and chronic dietary phosphate changes in mice. Moreover, we show that plasma levels of PTH but not FGF23 correlate with NaPi-Ila brush border membrane abundance, and that the FGF receptor adaptor protein FRS2 $\alpha$ but not the PTH receptor 1 is regulated during the adaption to low phosphate suggesting that PTH may play an important role in the very acute regulation of NaPi-lla during dietary adaption and that the kidney is able to adapt its sensitivity to FGF23 by regulating FGF receptor signaling. 


\section{NaPi-lla is the main phosphate transporter regulated by dietary phosphate intake in the mouse proximal tubule}

Our data demonstrate that both C57/BL6 mice and NaPi-Ila ${ }^{-/-}$mice were able to acutely regulate their plasma and urine phosphate levels. However, $\mathrm{NaPi}-\mathrm{Ila}^{-/ 2}$ mice reduced their blood $\mathrm{Pi}$ level more drastically when acutely challenged with low phosphate diet than C57/BL6. Moreover, they exhibited higher phosphaturia than C57/BL6 mice whatever the diet. Our data confirm previous observations on the role of NaPi-lla in chronic high and low phosphate diets in mice [7] and highlight the importance of $\mathrm{NaPi}-$ Ila in renal $\mathrm{Pi}$ handling during acute changes in phosphate intake in rodents. $\mathrm{NaPi}-\mathrm{Ila}^{-/-}$mice maintain their phosphate homeostasis, at least to some degree, by increasing the intestinal absorption of phosphate. This had been suggested as compensatory mechanism but never been tested before [7]. $1,25(\mathrm{OH})_{2} \mathrm{D}_{3}$ is elevated in $\mathrm{NaPi}-\mathrm{Ila}^{-/}$mice and may contribute to the adaptive response of the intestine observed in our study [7]. However, the small intestine is also able to adapt to low phosphate intake independent from vitamin $D_{3}$ or the vitamin $D_{3}$ receptor and thus vitamin $D_{3}$ independent mechanisms may be also involved [17]. Whether NaPi-Ila is equally important in human kidney for phosphate reabsorption and the fast adaption to dietary phosphate intake remains to be established. In contrast to rodents, NaPi-Ilc plays a more important role in human kidney, at least for total phosphate reabsorption [9]

In C57/BL6 mice, NaPi-Ila protein is very rapidly regulated by dietary phosphate intake. In the case of adapting to acute low phosphate diets, this involves most likely only translational or posttranslational mechanisms and trafficking of pre-synthesized $\mathrm{NaPi}$-lla transporter proteins. At the mRNA level, $\mathrm{NaPi}-$ Ila and $\mathrm{NaPi}$-Ilc were modulated chronically and also acutely after 4 hrs switching from low to high phosphate diet. Both immunoblotting and immunohistochemistry demonstrated a 
relocation of NaPi-lla into the brush border membrane after ingesting low phosphate and this was detectable after 4 hrs feeding. Similarly, intake of high phosphate caused downregulation and removal of NaPi-lla transporters from the BBM within 4 hrs demonstrating the importance of trafficking for the regulation of NaPi-lla function. Removed NaPi-lla transporters are then routed to lysosomes for degradation [26] whereas NaPi-llc may be recycled [43] or directly degraded [32, 44]. In our experiments we were unable to detect intracellular $\mathrm{NaPi}$-llc proteins by immunohistochemistry consistent with degradation of NaPi-llc proteins.

In parallel to the changes in phosphate transporter expression in the brush border membrane, we found adaption of $\mathrm{Na}^{+}$-dependent phosphate transport activity in brush border membrane vesicles prepared from C57/BL6 mice. In contrast, $\mathrm{Na}^{+}-$ dependent Pi-uptake into BBMV was very low and remained unchanged in $\mathrm{NaPi-lla-}{ }^{-1}$ mice whatever the diet. The remaining activity in knock-out BBM is approximately reduced to $30 \%$ under chronic high phosphate diet which is similar to what was described earlier $[50,56]$. This result indicates that NaPi-llc and Pit-2 transport activities are low in mice and may already be maximally stimulated in $\mathrm{NaPi}$-lla deficient mice as compensatory mechanism. Of note, NaPi-llc and Pit-2 were not able to compensate for the lack of $\mathrm{NaPi}-$ Ila as indicated by higher urinary phosphate losses under all conditions. However, $\mathrm{NaPi}-\mathrm{Ila}^{-/-}$mice were able to modulate total urinary phosphate excretion reducing phosphate excretion with low phosphate intake. Several mechanisms may be responsible for this adaption including lower filtered phosphate load due to lower circulating plasma phosphate levels, changes in glomerular filtration rate, or phosphate absorption in segments other than the proximal tubule. Micropuncture studies suggested also some phosphate absorption in distal portions of the nephron [36] and more recently the presence of NaPi-llb has been suggested [54]. 


\section{NaPi-lla is upregulated despite persistently high FGF23 level}

Changes in dietary phosphate intake were paralleled by plasma PTH levels; high phosphate intake associated with higher PTH levels and low phosphate diet associated with reduced PTH levels. The changes in PTH levels were achieved within at least 4 hrs after switching to high $\mathrm{Pi}$ intake and within less than $2 \mathrm{hrs}$ after ingesting low phosphate diets. Previous experiments in thyroparathyroidectomized rats showed that adaption from high to low Pi diet did not increase NaPi-lla abundance within 4 hrs whereas switching from low to high Pi reduced NaPi-lla protein after 4 hrs [55]. Since animals were not substituted with thyroid hormone no conclusions on the adaption from high to low Pi diets can be made. Moreover, shorter time points than 4 hrs were not investigated. The adaption to chronic $\mathrm{Pi}$ restriction intact in thyroparathyroidectomized rats demonstrating that neither PTH nor thyroid hormone are the major regulator in this setting $[53,62]$. Despite changes in PTH levels, the abundance of the PTH receptor 1 in the brush border membrane as well as in total kidney remained stable. Whether the receptor is regulated on the subcellular level, i.e. by endocytosis and recycling, remains to be examined in more detail.

The signals stimulating PTH secretion in response to elevated phosphate intake or reducing PTH levels after ingestion of low phosphate diets are not clear to date. While we cannot rule out small changes in ionized calcium levels altering PTH secretion, direct effects of phosphate on PTH synthesis and secretion may also contribute to regulation of parathyroid function. Direct effects of extracellular phosphate on PTH secretion by isolated parathyroid cells or slices under conditions of fixed concentrations of extracellular calcium have been described suggesting that phosphate independent from ionized calcium can stimulate PTH secretion [1-2, 41, 51]. The mechanism underlying this regulation is currently unknown. 
In contrast to PTH, FGF23 levels remained high for at least 8 hrs after switching from high to low phosphate intake. Similarly, FGF23 did not change over a period of 6 hours in healthy volunteers when plasma phosphate levels were acutely lowered [25]. Also in a more chronic setting, FGF23 levels decreased not before 16 hrs after switching healthy probands to a low phosphate diet [58]. Thus, FGF23 seems to adapt only slowly when the organism has to adapt from high to low phosphate intake. Nevertheless, in our model renal adaption of phosphate excretion, increased BBM phosphate transport activity, and enhanced $\mathrm{NaPi}$-Ila protein expression in the brush border membrane occurred much faster than 8 hrs despite the high FGF23 levels. These data suggest that PTH and possibly other factors may be more relevant for the rapid adaption from low to high phosphate intake and that the proximal tubule is resistant to the action of FGF23 during the acute adaption to low phosphate diet. The pathway by which FGF23 regulates NaPi-lla function and expression in the proximal tubule is controversial. FGF23 may act either indirectly on the proximal tubule via direct stimulation of a MAPK dependent pathway in the distal tubule [22] or may directly elicit an intracellular signaling cascade in the proximal tubule $[3,6,24]$. However, in all models, FGF23 signals via FGF1c receptors and its downstream adaptor protein FRS2 $\alpha$. We show now that the total abundance of FRS2 $\alpha$ and its

phosphorylated form are differently modulated during changes in dietary phosphate intake providing a possible explanation for the apparent resistance of the kidney to high circulating FGF23 levels during the switch from high to low Pi intake.

\section{Regulatory network in the renal adaption to dietary phosphate intake}

Several factor contribute to the adaption of the kidney to changes in phosphate intake. FGF23 and PTH contribute importantly to the downregulation of renal phosphate 
transporters, albeit with different time courses. In addition, sFRP4, MEPE, and dopamine have been identified as potential regulators. sFRP4 acutely downregulates renal phosphate reabsorption and $\mathrm{NaPi}-\mathrm{Ila}$ abundance in rat kidney [11], however, mice lacking sFRP4 adapt normally to changes in phosphate intake [18]. MEPE reduces renal phosphate reabsorption [21, 31] and MEPE deficient mice display hyperphosphatemia with elevated expression of $\mathrm{NaPi}$-lla consistent with a phosphaturic role of MEPE [20]. However, the role of MEPE in the acute renal adaption to changes in dietary phosphate intake has not been determined. In addition, locally produced dopamine may contribute to the downregulation of NaPi-lla during intake of high phosphate, an effect mediated by D1-like dopamine receptors [4, 61]. A role of the small intestine in sensing the phosphate load and inducing the renal adaption has been proposed but a subsequently published erratum indicates that very high phosphate loads were given [10]. Thus, even though several hormones besides PTH and FGF23 may be involved in adapting the kidney to increased dietary phosphate intake, the role of the small intestine remains to be clarified. The relative contribution of these factors to regulating renal phosphate handling may vary over time as indicated by the different time courses for PTH and FGF23 elevation and fall upon changes in dietary $\mathrm{Pi}$ intake. The response time and time course of other factors such as dopamine and MEPE have not been determined in enough detail to integrate them into a more detailed model to date.

In summary, we demonstrate that NaPi-Ila is the main phosphate transporter in mouse kidney and critical for the adaptive capacity of the proximal tubule to adapt to dietary phosphate intake. However, NaPi-Ila deficient mice showed some ability to adapt their renal excretion of phosphate to dietary intake. During the acute adaption to low phosphate intake, $\mathrm{NaPi}$-Ila is rapidly recruited to the brush border membrane 
within 4 hrs despite persistently high FGF23 level suggesting that PTH may mediate at least in part the acute adaption to dietary phosphate.

\section{ACKNOWLEDGEMENTS}

The authors thank N. Hernando for fruitful discussions. The use of the ZIRP Core facility for Rodent Physiology is acknowledged. The study was supported by the Swiss National Center for Competence in Research NCCR Kidney.CH to J. Biber and C.A. Wagner. 
Table 1. Metabolic values in C57BL6 and NaPi-lla ${ }^{-/}$during a 4 hrs period of feeding and collecting period with chronic and acute high and low phosphate diets (day 9)

\begin{tabular}{|c|c|c|c|c|c|c|c|c|}
\hline & \multicolumn{2}{|c|}{ High Pi diet } & \multicolumn{2}{|c|}{ High to Low Pi diet } & \multicolumn{2}{|c|}{ Low Pi diet } & \multicolumn{2}{|c|}{ Low to High Pi diet } \\
\hline & $\begin{array}{c}C 57 / B L 6 \\
(n=5)\end{array}$ & 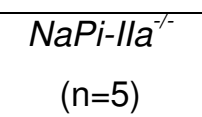 & $\begin{array}{c}C 57 / B L 6 \\
(n=5)\end{array}$ & $\begin{array}{c}\mathrm{NaPi}-\mathrm{Ila} \mathrm{F}^{-1-} \\
(\mathrm{n}=5)\end{array}$ & $\begin{array}{c}C 57 / B L 6 \\
(n=5)\end{array}$ & $\begin{array}{c}\mathrm{NaPi}-\mathrm{Ila}{ }^{-1-} \\
(\mathrm{n}=7)\end{array}$ & $\begin{array}{c}\text { C57/BL6 } \\
(\mathrm{n}=5)\end{array}$ & $\begin{array}{c}\mathrm{NaPi}-\mathrm{Ila}{ }^{-1-} \\
(\mathrm{n}=7)\end{array}$ \\
\hline $\begin{array}{l}\text { Mice weight (g) } \\
\text { Food intake } \\
\text { (g/4hrs/body weight) }\end{array}$ & $\begin{array}{l}21.9 \pm 1.0 \\
0.13 \pm 0.01\end{array}$ & $\begin{array}{l}19.1 \pm 0.2 \\
0.10 \pm 0.02\end{array}$ & $\begin{array}{c}22.5 \pm 1.4 \\
0.08 \pm 0.01^{\#}\end{array}$ & $\begin{array}{l}21.1 \pm 0.6 \\
0.12 \pm 0.00\end{array}$ & $\begin{array}{c}25.8 \pm 0.9 \\
0.06 \pm 0.00^{\#}\end{array}$ & $\begin{array}{l}19.5 \pm 0.4 \\
0.09 \pm 0.01\end{array}$ & $\begin{array}{l}23.4 \pm 0.9 \\
0.11 \pm 0.00\end{array}$ & $\begin{array}{l}20.8 \pm 0.8 \\
0.09 \pm 0.01\end{array}$ \\
\hline $\begin{array}{l}\text { Plasma: } \\
\text { Phosphate (mM) } \\
\text { Calcium (mM) }\end{array}$ & $\begin{array}{c}2.42 \pm 0.20 \\
1.82 \pm 0.05(9)\end{array}$ & $\begin{array}{c}1.95 \pm 0.44 \\
N D\end{array}$ & $\begin{array}{l}1.09 \pm 0.18^{\#} \\
1.91 \pm 0.08\end{array}$ & $\begin{array}{c}0.34 \pm 0.03^{\#} \\
\mathrm{ND}\end{array}$ & $\begin{array}{c}0.50 \pm 0.06^{\#} \\
2.07 \pm 0.04(6)^{\#}\end{array}$ & $\begin{array}{c}0.32 \pm 0.09^{\#} \\
\text { ND }\end{array}$ & $\begin{array}{l}2.20 \pm 0.07 \\
1.71 \pm 0.14\end{array}$ & $\begin{array}{c}1.45 \pm 0.17 \\
\text { ND }\end{array}$ \\
\hline $\begin{array}{l}\text { Urine: } \\
\text { creatinine }(\mu \mathrm{mol} / 4 \mathrm{hrs})\end{array}$ & $0.16 \pm 0.04$ & $0.14 \pm 0.01$ & $0.18 \pm 0.03$ & $0.12 \pm 0.01$ & $0.16 \pm 0.05$ & $0.14 \pm 0.02$ & $0.26 \pm 0.05$ & $0.13 \pm 0.01^{*}$ \\
\hline $\mathrm{Pi} /$ creatinine $(\mathrm{mM} / \mathrm{mM})$ & $42.3 \pm 2.8$ & $53.6 \pm 5.4$ & $4.9 \pm 2.7^{\#}$ & $21.7 \pm 0.8^{\star \#}$ & $1.0 \pm 0.1^{\#}$ & $7.7 \pm 2.0^{\star \#}$ & $28.7 \pm 2.1^{\#}$ & $36.2 \pm 4.4^{\#}$ \\
\hline
\end{tabular}

${ }^{*} \mathrm{p}<0.05$ versus C57/BL6 under same diet, ${ }^{\#} \mathrm{p}<0.05$ versus same genotype under High Pi diet 
Table 2. Metabolic values in C57BL6 and $\mathrm{NaPi}-1 / \mathrm{a}^{-/-}$during $4 \mathrm{hrs}$ feeding/ day and $24 \mathrm{hrs}$ collecting period with chronic high and low phosphate diets (day 8)

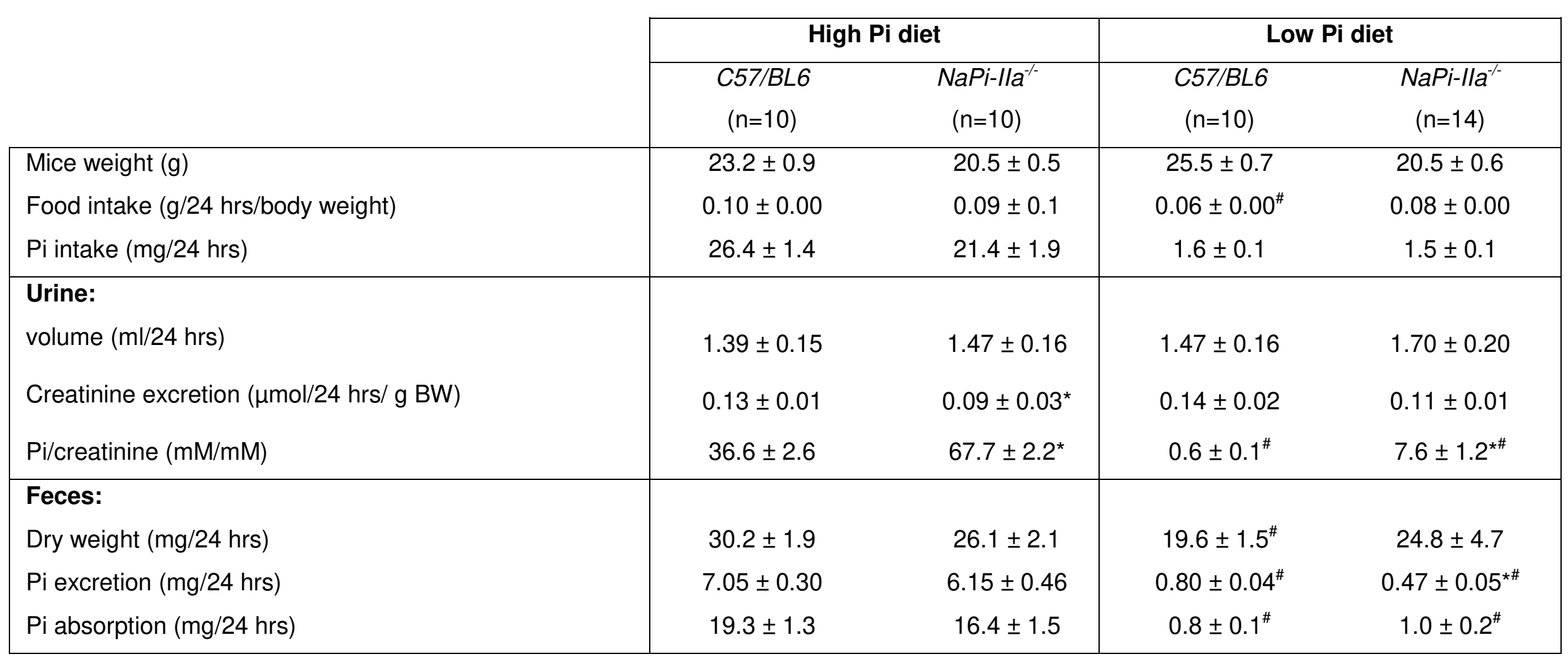

${ }^{*} p<0.05$ versus C57/BL6 under same diet, ${ }^{\#} p<0.05$ versus same genotype under high Pi diet 
Table 3. PTH and FGF23 values in plasma from C57/BL6 mice during 4 hrs feeding chronic and acute high and low dietary phosphate

\begin{tabular}{|c|c|c|c|c|}
\hline & High Pi diet & High to Low Pi diet & Low Pi diet & Low to High Pi diet \\
\hline & $(n=8)$ & $(n=10)$ & $(n=9)$ & $(n=9)$ \\
\hline PTH (pg/ml) & $623 \pm 156$ & $61 \pm 23^{*}$ & $127 \pm 22$ & $576 \pm 147^{*}$ \\
\hline FGF23 (pg/ml) & $395 \pm 74$ & $340 \pm 41$ & $218 \pm 42$ & $454 \pm 67$ \\
\hline
\end{tabular}

${ }^{*} p<0.05$ versus chronic diet 
Table 4. PTH and FGF23 values in plasma from C57BL6 during a High to Low phosphate diet switch

\begin{tabular}{|l|c|c|c|c|}
\cline { 2 - 5 } \multicolumn{1}{c|}{} & High Pi diet & $\begin{array}{c}\text { 2 hrs } \\
\text { High to Low Pi diet }\end{array}$ & High to Low Pi diet & $\begin{array}{c}\text { 8 hrs } \\
\text { High to Low Pi diet }\end{array}$ \\
\cline { 2 - 5 } & $(\mathrm{n}=8)$ & $(\mathrm{n}=5)$ & $(\mathrm{n}=10)$ & $(\mathrm{n}=5)$ \\
\hline PTH $(\mathrm{pg} / \mathrm{ml})$ & $623 \pm 156$ & $30 \pm 10^{*}$ & $61 \pm 23^{*}$ & $75 \pm 8^{*}$ \\
FGF23 $(\mathrm{pg} / \mathrm{ml})$ & $395 \pm 74$ & $461 \pm 36$ & $340 \pm 41$ & $402 \pm 35$ \\
\hline
\end{tabular}

${ }^{*} p<0.05$ vs High Pi diet 


\section{FIGURE LEGENDS}

Figure 1: Plasma phosphate levels during acute and chronic changes in dietary Pi.

A: Plasma $\mathrm{Pi}$ in C57/BL6 mice ( $\mathrm{n}=5$ mice/ group). B: Plasma Pi in NaPilla ${ }^{-/-}$mice ( $\mathrm{n}$ $=5$ to 7 mice/ group). C57/BL6 and NaPi-lla ${ }^{-/-}$mice were fed 4 hrs per day with high (HPD) or low Pi (LPD) containing diets for 4 days. Some mice were switched on the last day from high to low (H/LPD) or from low to high (L/HPD) Pi containing diets. Both strains of mice were able to modulate their blood Pi during these dietary conditions. However, $\mathrm{NaPi}-\mathrm{Ila}^{-/-}$mice more drastically decreased their bood Pi level during the acute H/LPD switch. ${ }^{*} p<0.05$.

\section{Figure 2: Urine Pi excretion during chronic and acute changes in dietary Pi}

A: Urinary Pi in C57/BL6 mice ( $n=4$ to 6 mice/ group). B: Urinary Pi in NaPilla ${ }^{-/-}$mice ( $\mathrm{n}=5$ to 7 mice/ group). C57/BL6 mice and NaPi-Ila ${ }^{-/-}$mice were fed 4 hrs per day with high (HPD) or low Pi (LPD) containing diets for 4 days. Some mice were switched on the last day from high to low (H/LPD) or from low to high (L/HPD) Pi containing diets. Both strains of mice were able to modulate their urinary Pi excretion during these dietary conditions. However, NaPi-Ila ${ }^{-/}$mice lost more $\mathrm{Pi}$ into urine compared to C57/BL6 mice whatever the diet. ${ }^{*} \mathrm{p}<0.05$.

Figure 3: Intestinal $\mathrm{Pi}$ absorption in C57/BL6 and $\mathrm{NaPi}-1 / a^{-/-}$mice during high and low Pi diets.

$\mathrm{Pi}$ excretion was determined in feces from $4 \mathrm{hrs} /$ day feeding mice treated with chronic high (HPD) or low (LPD) Pi diets for 4 days. Pi absorption was estimated from the total daily amount of Pi consumption minus the daily Pi excretion in 24 hrs 
fecal collections on the last day. $\mathrm{P}<0.05, \mathrm{n}=10$ to 13 mice/group. NaPi-lla ${ }^{-/-}$mice increased Pi absorption compared to C57/B6 mice during LPD.

Figure 4: Brush border membrane (BBM) sodium-dependent phosphate (NaPi) transport activity in C57/BL6 and NaPi-Ila ${ }^{-/ 2}$ mice. Sodium-dependent ${ }^{32} \mathrm{P}$-uptake was determined in BBMV from C57/BL6 and NaPi-lla ${ }^{-/-}$mice during acute and chronic phosphate diets. A: BBMV prepared from C57/BL6 mice demonstrated that dietary phosphate intake modulates $\mathrm{Na}^{+}$-dependent $\mathrm{Pi}$ cotransport activity acutely and chronically. B: In contrast, in BBMV prepared from NaPi-Ila-- mice $\mathrm{Na}^{+}$-dependent $\mathrm{Pi}$ cotransport activity was always lower than in C57/BL6 mice and did not show any regulation. $\mathrm{n}=5$ to 7 mice/group, ${ }^{*} p<0.05$

Figure 5: Dietary phosphate intake regulates $\mathrm{NaPi}-\mathrm{Ila}$ and NaPi-Ilc transcripts but not Pit-2 mRNA. Real-time PCR was used to assess NaPi-Ila, NaPi-Ilc and Pit-2 mRNA levels in total kidneys from C57/BL6 and NaPi-lla ${ }^{-/-}$mice. A: NaPi-Ila mRNA levels were modulated by dietary Pi intake. B: NaPi-Ilc mRNA level was modulated in C57/BL6 kidneys except during H/LPD but was very low and did not adapt to dietary phosphate intake in NaPi-Ila ${ }^{-/}$kidneys. C: Pit-2 mRNA level was not regulated by chronic dietary phosphate intake in both C57/BL6 and NaPi-Ila ${ }^{-/-}$mice. $n=4$ to 8 mice/group. ${ }^{*} p<0.05$

Figure 6: Brush border membrane abundance of NaPi-lla, NaPi-llc and Pit-2 adapts to continuous chronic dietary phosphate intake in C57/BL6 mice.

Brush border membranes were prepared from mice kept over 24 hrs on high or low phosphate diets for 5 days. A: Representative immunoblottings for NaPi-Ila, NaPi-Ilc and Pit-2. All blots were normalized against total protein amount stained on parallel 
Coomassie blue gels (see Methods sections). B-D: Bar graphs summarizing data from immunoblottings showing mean \pm SEM ( $n=5$ mice/ group). All data were normalized to the HPD (set as $100 \%$ ). BBM NaPi-Ila, NaPi-Ilc and Pit-2 protein abundance was significantly higher during chronic LPD. * $p<0.05$.

Figure 7: Rapid adaption of NaPi-lla brush border membrane abundance during $4 \mathrm{hrs}$ feeding acute and chronic phosphate in C57/BL6 mice.

Brush border membranes were prepared from mice receiving only for 4 hrs/ day high (HPD) or low (LPD) phosphate diets for 4 days. Some mice were switched on the last day from high to low phosphate (H/LPD) or from low to high phosphate diet (L/HPD). A: Representative immunoblottings for NaPi-lla, NaPi-Ilc and Pit-2 during acute phosphate diets. All blots were normalized against total protein amount stained on Coomassie blue gels (see Methods sections). B-D: Bar graphs summarizing data from immunoblotting showing mean \pm SEM ( $n=5$ mice/ group). All data were normalized to the HPD (set as $100 \%$ ). Only NaPi-Ila BBM expression was modulated by acute phosphate diets. NaPi-llc protein abundance exhibited only a change between HPD and LPD and Pit-2 protein abundance, no significant change. * $\mathrm{p}<0.05$.

Figure 8: Immunolocalization of NaPi-lla, NaPi-llc and Pit-2 cotransporters in kidneys from C57/BL6 mice during acute and chronic changes in dietary phosphate intake.

Kidney sections were prepared from mice receiving only for $4 \mathrm{hrs} /$ day high (HPD) or low (LPD) phosphate diets for 4 days. Some mice were switched on the last day from high to low phosphate (H/LPD) or from low to high phosphate diet (L/HPD). All animals were fixed by perfusion $4 \mathrm{hrs}$ after receiving the last diet. NaPi-Ila (A), NaPi- 
IIc (B), and Pit-2 (C) stainings are shown in red, the brush border membrane marked by labeling fo actin (green), nuclei are stained with DAPI (blue). Pictures were taken from juxtamedullary $\mathrm{S} 1$ proximal tubule segments. Only NaPi-lla staining was observed both at the plasma membrane and in intracellular organelles possibly representing Golgi apparatus. NaPi-llc and Pit-2 were detected only at the plasma membrane. During LPD all three transporters were detected abundantly in the BBM (yellow overlay), whereas during HPD only weak staining was observed in the BBM. The H/LPD switch induced NaPi-lla and NaPi-Ilc staining in the BBM whereas Pit-2 was not detected. Similarly, the L/HPD showed reduced BBM localization of NaPi-lla and NaPi-Ilc and no detectable signal for Pit-2. Original magnification 40x.

Figure 9: Plasma PTH and FGF23 in C57/BL6 mice during acute and chronic high and low phosphate diets. Plasma PTH level was rapidly regulated by dietary phosphate within 4 hrs of switching while plasma FGF23 was significantly modulated only when mice were switched from low to high phosphate diet. ${ }^{*} p<0.05$ versus chronic diets ( $\mathrm{n}=8$ to 10 mice/group).

Figure 10: FRS2 $\alpha$ and p-FRS2 $\alpha$ adapt to dietary phosphate intake whereas the PTH receptor 1 is not altered.

Brush border membranes and whole kidney homogenates were prepared from mice receiving only for $4 \mathrm{hrs}$ / day high (HPD) or low (LPD) phosphate diets for 4 days. Some mice were switched on the last day from high to low phosphate (H/LPD) or from low to high phosphate diet (L/HPD). A: Representative immunoblottings for FRS2 $\alpha$, p-FRS2 $\alpha$ and PTH receptor 1 during acute phosphate diets. All blots were normalized against total protein amount stained on Coomassie blue gels. B: Bar 
graph summarizing data from immunoblots showing mean \pm SEM $(n=5$ mice/ group). All data were normalized to the HPD group (set as $100 \%$ ). FRS2 $\alpha$ expression in whole kidney homogenates was acutely modulated by dietary phosphate. p-FRS2 $\alpha$ expression in whole kidney homogenates was modulated only during the acute HPD to LPD switch. BBM expression of the PTH receptor 1 was not modulated by phosphate diets. ${ }^{*} p<0.05$

Figure 11: Plasma PTH and FGF23 changes over $8 \mathrm{hrs}$ after switching from high to low dietary phosphate intake. Mice were trained to eat for 4 hrs a day during 4 days high phosphate diet. On the fifth day, mice were subdivided into 4 groups: group 1 receiving a HPD, groups 2-4 receiving LPD for 2 hrs, 4 hrs and 8 hrs, respectively. A: Plasma PTH was reduced in all groups receiving the LPD whereas B: FGF23 remained high until 8 hrs LPD. ${ }^{*} p<0.05$ versus HPD. ( $n=5$ to 10 mice/group).

Figure 12: The adaptor protein FRS2 $\alpha$ and its phorphorylated form p-FRS2 $\alpha$ are acutely modulated after switching from high to low dietary phosphate intake. Mice were trained to eat 4 hrs per day during 4 days HPD. On the fifth day, mice were subdivided into 4 groups: group 1 receiving HPD, and groups 2-4 feeding LPD for 2 hrs, 4 hrs, or 8 hrs, respectively. Whole kidney homogenates and BBM were prepared and FRS2 $\alpha, \mathrm{p}-\mathrm{FRS} 2 \alpha$ and PTH receptor 1 abundance were determined by western-blotting. A: Representative immunoblottings for FRS2 $\alpha, \mathrm{p}-\mathrm{FRS} 2 \alpha$ and PTH receptor 1 during a 2 hrs, 4 hrs ans 8 hrs HPD to LPD switch. All blots were normalized against total protein amount stained on Coomassie blue gels. B: Bar graph summarizing data from immunoblotting showing mean \pm SEM $(n=5$ mice/ group). All data were normalized to the HPD group (set as $100 \%$ ). FRS2 $\alpha$ and p- 
FRS2 $\alpha$ whole kidney expression decreased after respectively a 4hrs and 2 hrs feeding LPD. $\mathrm{n}=5$ mice/ group,. BBM expression of the PTH receptor 1 was unchanged during the treatments. ${ }^{*} p<0.05$ versus HPD

Figure 13: Dietary phosphate intake induces rapid regulation of NaPi-lla protein abundance. Mice were trained to eat 4 hrs per day during 4 days HPD. On the fifth day, mice were subdivided into 4 groups: group 1 receiving HPD, and groups 2-4 feeding LPD for 2 hrs, 4 hrs, or $8 \mathrm{hrs}$, respectively. BBM were prepared and NaPi-lla abundance was determined by western-blotting. BBM NaPi-lla levels were significantly increased after 4 hrs after feeding LPD. $n=5$ to 8 mice/ group, * $p<0.05$ versus HPD. 


\section{REFERENCES}

1. Almaden Y, Canalejo A, Hernandez A, Ballesteros E, Garcia-Navarro S, Torres A, Rodriguez M (1996) Direct effect of phosphorus on PTH secretion from whole rat parathyroid glands in vitro. J Bone Miner Res 11:970-6 DOI Electronic Resource Number

2. Almaden Y, Hernandez A, Torregrosa V, Canalejo A, Sabate L, Fernandez Cruz L, Campistol JM, Torres A, Rodriguez M (1998) High phosphate level directly stimulates parathyroid hormone secretion and synthesis by human parathyroid tissue in vitro. $\mathrm{J}$ Am Soc Nephrol 9:1845-52 DOI Electronic Resource Number

3. Andrukhova O, Zeitz U, Goetz R, Mohammadi M, Lanske B, Erben RG (2012) FGF23 acts directly on renal proximal tubules to induce phosphaturia through activation of the ERK1/2-SGK1 signaling pathway. Bone Resource Number

4. Bacic D, Capuano P, Baum M, Zhang J, Stange G, Biber J, Kaissling B, Moe OW, Wagner CA, Murer H (2005) Activation of dopamine D1-like receptors induces acute internalization of the renal $\mathrm{Na}+$ /phosphate cotransporter $\mathrm{NaPi}$-lla in mouse kidney and OK cells. Am J Physiol Renal Physiol 288:F740-7 DOI Electronic Resource Number

5. Bacic D, Lehir M, Biber J, Kaissling B, Murer H, Wagner CA (2006) The renal $\mathrm{Na}+$ /phosphate cotransporter $\mathrm{NaPi}-\mathrm{lla}$ is internalized via the receptor-mediated endocytic route in response to parathyroid hormone. Kidney Int 69:495-503 DOI Electronic Resource Number

6. Baum M, Schiavi S, Dwarakanath V, Quigley R (2005) Effect of fibroblast growth factor-23 on phosphate transport in proximal tubules. Kidney Int 68:1148-53 DOI Electronic Resource Number

7. Beck L, Karaplis, A C, Amizuka, N, Hewson, A S, Ozawa, H, Tenenhouse, H S (1998) Targeted inactivation of Npt2 in mice leads to severe renal phosphate wasting, hypercalciuria, and skeletal abnormalities. Proc Natl Acad Sci U S A 95:5372-7 DOI Electronic Resource Number

8. Bergwitz C, Juppner H (2010) Regulation of phosphate homeostasis by PTH, vitamin D, and FGF23. Annu Rev Med 61:91-104 DOI Electronic Resource Number

9. Bergwitz C, Roslin, N M, Tieder, M, Loredo-Osti, J C, Bastepe, M, Abu-Zahra, H, Frappier, D, Burkett, K, Carpenter, T. O, Anderson, D, Garabedian, M, Sermet, I, Fujiwara, T M, Morgan, K, Tenenhouse, H S, Juppner, H (2006) SLC34A3 mutations in patients with hereditary hypophosphatemic rickets with hypercalciuria predict a key role for the sodium-phosphate cotransporter $\mathrm{NaP}(\mathrm{i})$-Ilc in maintaining phosphate homeostasis. Am. J. Hum. Genet. 78:179-192 DOI Electronic Resource Number

10. Berndt T, Thomas LF, Craig TA, Sommer S, Li X, Bergstralh EJ, Kumar R (2007) Evidence for a signaling axis by which intestinal phosphate rapidly modulates renal phosphate reabsorption. Proc Natl Acad Sci U S A 104:11085-11090 DOI Electronic Resource Number 
11. Berndt TJ, Bielesz B, Craig TA, Tebben PJ, Bacic D, Wagner CA, O'Brien S, Schiavi S, Biber J, Murer H, Kumar R (2006) Secreted frizzled-related protein-4 reduces sodium-phosphate co-transporter abundance and activity in proximal tubule cells. Pflugers Arch 451:579-87 DOI Electronic Resource Number

12. Biber J, Hernando N, Forster I, Murer H (2009) Regulation of phosphate transport in proximal tubules. Pflugers Arch 458:39-52 DOI Electronic Resource Number

13. Biber J, Stieger B, Stange G, Murer $\mathrm{H}$ (2007) Isolation of renal proximal tubular brush-border membranes. Nat Protoc 2:1356-9 DOI Electronic Resource Number

14. Biber J, Stieger, B, Haase, W, Murer, H (1981) A high yield preparation for rat kidney brush border membranes. Different behaviour of lysosomal markers. Biochim Biophys Acta 647:169-76 DOI Electronic Resource Number

15. Breusegem SY, Takahashi H, Giral-Arnal H, Wang X, Jiang T, Verlander JW, Wilson P, Miyazaki-Anzai S, Sutherland E, Caldas Y, Blaine JT, Segawa H, Miyamoto K, Barry NP, Levi M (2009) Differential regulation of the renal sodiumphosphate cotransporters NaPi-lla, NaPi-llc, and PiT-2 in dietary potassium deficiency. Am J Physiol Renal Physiol 297:F350-61 DOI Electronic Resource Number

16. Capuano P, Bacic D, Stange G, Hernando N, Kaissling B, Pal R, Kocher O, Biber $\mathrm{J}$, Wagner CA, Murer $\mathrm{H}$ (2005) Expression and regulation of the renal $\mathrm{Na} /$ phosphate cotransporter NaPi-Ila in a mouse model deficient for the PDZ protein PDZK1. Pflugers Arch 449:392-402 DOI Electronic Resource Number

17. Capuano $P$, Radanovic $T$, Wagner $C A$, Bacic D, Kato S, Uchiyama $Y$, St-Arnoud $\mathrm{R}$, Murer H, Biber J (2005) Intestinal and renal adaptation to a low-Pi diet of type II $\mathrm{NaPi}$ cotransporters in vitamin $\mathrm{D}$ receptor- and 1alphaOHase-deficient mice. Am J Physiol Cell Physiol 288:C429-34 DOI Electronic Resource Number

18. Christov M, Koren S, Yuan Q, Baron R, Lanske B (2011) Genetic ablation of sfrp4 in mice does not affect serum phosphate homeostasis. Endocrinology 152:2031-6 DOI Electronic Resource Number

19. Custer M, Lötscher, M, Biber, J, Murer, H, Kaissling, B (1994) Expression of Na$\mathrm{P}_{\mathrm{i}}$ cotransport in rat kidney: localization by RT-PCR and immunohistochemistry. Am J Physiol 266:F767-74 DOI Electronic Resource Number

20. David V, Martin A, Hedge AM, Rowe PS (2009) Matrix extracellular phosphoglycoprotein (MEPE) is a new bone renal hormone and vascularization modulator. Endocrinology 150:4012-23 DOI Electronic Resource Number

21. Dobbie H, Unwin RJ, Faria NJ, Shirley DG (2008) Matrix extracellular phosphoglycoprotein causes phosphaturia in rats by inhibiting tubular phosphate reabsorption. Nephrol Dial Transplant 23:730-3 DOI Electronic Resource Number

22. Farrow EG, Davis SI, Summers LJ, White KE (2009) Initial FGF23-mediated signaling occurs in the distal convoluted tubule. J Am Soc Nephrol 20:955-60 DOI Electronic Resource Number 
23. Fiske $\mathrm{CH}$, SubbaRow $\mathrm{Y}$ (1925) The colorometric determination of phosphorus. J Biol Chem 66:375-400 DOI Electronic Resource Number

24. Hu MC, Shi M, Zhang J, Pastor J, Nakatani T, Lanske B, Shawkat Razzaque M, Rosenblatt KP, Baum MG, Kuro OM, Moe OW (2010) Klotho: a novel phosphaturic substance acting as an autocrine enzyme in the renal proximal tubule. FASEB $\mathrm{J}$ Resource Number

25. Ito N, Fukumoto S, Takeuchi $Y$, Takeda S, Suzuki H, Yamashita T, Fujita T (2007) Effect of acute changes of serum phosphate on fibroblast growth factor (FGF)23 levels in humans. J Bone Miner Metab 25:419-22 DOI Electronic Resource Number

26. Keusch I, Traebert, M, Lötscher, M, Kaissling, B, Murer, H, Biber, J (1998) Parathyroid hormone and dietary phosphate provoke a lysosomal routing of the proximal tubular Na/Pi-cotransporter type II. Kidney Int 54:1224-32 DOI Electronic Resource Number

27. Kurosu H, Ogawa Y, Miyoshi M, Yamamoto M, Nandi A, Rosenblatt KP, Baum MG, Schiavi S, Hu MC, Moe OW, Kuro-o M (2006) Regulation of fibroblast growth factor-23 signaling by klotho. J Biol Chem 281:6120-3 DOI Electronic Resource Number

28. Lanzano L, Lei T, Okamura K, Giral H, Caldas Y, Masihzadeh O, Gratton E, Levi M, Blaine $J$ (2011) Differential modulation of the molecular dynamics of the type Ila and Ilc sodium phosphate cotransporters by parathyroid hormone. Am J Physiol Cell Physiol 301:C850-61 DOI Electronic Resource Number

29. Levi M, Lötscher, M, Sorribas, V, Custer, M, Arar, M, Kaissling, B, Murer, H, Biber, J (1994) Cellular mechanisms of acute and chronic adaptation of rat renal $\mathrm{Pi}_{\mathrm{i}}$ transporter to alterations in dietary $\mathrm{P}_{\mathrm{i}}$. Am J Physiol 267:F900-8 DOI Electronic Resource Number

30. Lötscher M, Wilson, P, Nguyen, S, Kaissling, B, Biber, J, Murer, H, Levi, M (1996) New aspects of adaptation of rat renal $\mathrm{Na}-\mathrm{Pi}$ cotransporter to alterations in dietary phosphate. Kidney Int 49:1012-8 DOI Electronic Resource Number

31. Marks J, Churchill LJ, Debnam ES, Unwin RJ (2008) Matrix extracellular phosphoglycoprotein inhibits phosphate transport. J Am Soc Nephrol 19:2313-20 DOI Electronic Resource Number

32. Matsumoto N, Hemmi A, Yamato H, Ohnishi R, Segawa H, Ohno S, Miyamoto K (2010) Immunohistochemical analyses of parathyroid hormone-dependent downregulation of renal type II Na-Pi cotransporters by cryobiopsy. J Med Invest 57:138-45 DOI Electronic Resource Number

33. Miyamoto K, Haito-Sugino S, Kuwahara S, Ohi A, Nomura K, Ito M, Kuwahata M, Kido S, Tatsumi S, Kaneko I, Segawa H (2011) Sodium-dependent phosphate cotransporters: lessons from gene knockout and mutation studies. J Pharm Sci 100:3719-30 DOI Electronic Resource Number

34. Miyamoto KI, Itho M (2001) Transcriptional regulation of the NPT2 gene by dietary phosphate. Kidney Int 60:412-5 DOI Electronic Resource Number 
35. Mohebbi N, Kovacikova J, Nowik M, Wagner CA (2007) Thyroid hormone deficiency alters expression of acid-base transporters in rat kidney. Am $\mathrm{J}$ Physiol Renal Physiol 293:F416-27 DOI Electronic Resource Number

36. Muhlbauer RC, Bonjour JP, Fleisch H (1977) Tubular localization of adaptation to dietary phosphate in rats. Am J Physiol 233:F342-8 DOI Electronic Resource Number

37. Murer H, Biber J (2010) Phosphate transport in the kidney. J Nephrol 23 Suppl 16:S145-51 DOI Electronic Resource Number

38. Murer H, Forster, I, Biber, J (2004) The sodium phosphate cotransporter family SLC34. Pflugers Arch 447:763-7 DOI Electronic Resource Number

39. Murer H, Hernando, N, Forster, I, Biber, J (2000) Proximal tubular phosphate reabsorption: molecular mechanisms. Physiol Rev 80:1373-409 DOI Electronic Resource Number

40. Murer H, Hernando, N, Forster, I, Biber, J (2003) Regulation of Na/Pi transporter in the proximal tubule. Annu Rev Physiol 65:531-42 DOI Electronic Resource Number

41. Nielsen PK, Feldt-Rasmussen U, Olgaard K (1996) A direct effect in vitro of phosphate on PTH release from bovine parathyroid tissue slices but not from dispersed parathyroid cells. Nephrol Dial Transplant 11:1762-8 DOI Electronic Resource Number

42. Nowik M, Picard N, Stange G, Capuano P, Tenenhouse HS, Biber J, Murer H, Wagner CA (2008) Renal phosphaturia during metabolic acidosis revisited: molecular mechanisms for decreased renal phosphate reabsorption. Pflugers Arch 457:539-49 DOI Electronic Resource Number

43. Ohkido I, Segawa H, Yanagida R, Nakamura M, Miyamoto K (2003) Cloning, gene structure and dietary regulation of the type-Ilc Na/Pi cotransporter in the mouse kidney. Pflugers Arch 446:106-15 DOI Electronic Resource Number

44. Picard N, Capuano P, Stange G, Mihailova M, Kaissling B, Murer H, Biber J, Wagner CA (2010) Acute parathyroid hormone differentially regulates renal brush border membrane phosphate cotransporters. Pflugers Arch 460:677-87 DOI Electronic Resource Number

45. Quentin F, Chambrey R, Trinh-Trang-Tan MM, Fysekidis M, Cambillau M, Paillard M, Aronson PS, Eladari D (2004) The $\mathrm{Cl}^{-} / \mathrm{HCO}_{3}{ }^{-}$exchanger pendrin in the rat kidney is regulated in response to chronic alterations in chloride balance. Am J Physiol Renal Physiol 287:F1179-88 DOI Electronic Resource Number

46. Ravera S, Virkki LV, Murer H, Forster IC (2007) Deciphering PiT transport kinetics and substrate specificity using electrophysiology and flux measurements. Am J Physiol Cell Physiol 293:C606-20 DOI Electronic Resource Number

47. Razzaque MS (2009) The FGF23-Klotho axis: endocrine regulation of phosphate homeostasis. Nat Rev Endocrinol 5:611-9 DOI Electronic Resource Number 
48. Ritthaler T, Traebert M, Lotscher M, Biber J, Murer H, Kaissling B (1999) Effects of phosphate intake on distribution of type II Na/Pi cotransporter mRNA in rat kidney. Kidney Int 55:976-83 DOI Electronic Resource Number

49. Segawa H, Kaneko I, Takahashi A, Kuwahata M, Ito M, Ohkido I, Tatsumi S, Miyamoto K (2002) Growth-related renal type II Na/Pi cotransporter. J Biol Chem 277:19665-72 DOI Electronic Resource Number

50. Segawa H, Onitsuka A, Kuwahata M, Hanabusa E, Furutani J, Kaneko I, Tomoe $\mathrm{Y}$, Aranami F, Matsumoto N, Ito M, Matsumoto M, Li M, Amizuka N, Miyamoto K (2009) Type Ilc sodium-dependent phosphate transporter regulates calcium metabolism. J Am Soc Nephrol 20:104-13 DOI Electronic Resource Number

51. Slatopolsky E, Finch J, Denda M, Ritter C, Zhong M, Dusso A, MacDonald PN, Brown AJ (1996) Phosphorus restriction prevents parathyroid gland growth. High phosphorus directly stimulates PTH secretion in vitro. J Clin Invest 97:2534-40 DOI Electronic Resource Number

52. Slot C (1965) Plasma creatinine determination. A new and specific Jaffe reaction method. Scand J Clin Lab Invest 17:381-7 DOI Electronic Resource Number

53. Stoll R, Kinne, R, Murer, H (1979) Effect of dietary phosphate intake on phosphate transport by isolated rat renal brush-border vesicles. Biochem $\mathrm{J}$ 180:46570 DOI Electronic Resource Number

54. Suyama T, Okada S, Ishijima T, lida K, Abe K, Nakai Y (2012) High phosphorus diet-induced changes in NaPi-Illb phosphate transporter expression in the rat kidney: DNA microarray analysis. PLoS One 7:e29483 DOI Electronic Resource Number

55. Takahashi F, Morita K, Katai K, Segawa H, Fujioka A, Kouda T, Tatsumi S, Nii T, Taketani Y, Haga H, Hisano S, Fukui Y, Miyamoto KI, Takeda E (1998) Effects of dietary $\mathrm{Pi}$ on the renal $\mathrm{Na}+$-dependent $\mathrm{Pi}$ transporter $\mathrm{NaPi}-2$ in thyroparathyroidectomized rats. Biochem J 333 ( Pt 1):175-81 DOI Electronic Resource Number

56. Tenenhouse HS, Martel J, Gauthier C, Segawa H, Miyamoto K (2003) Differential effects of Npt2a gene ablation and X-linked Hyp mutation on renal expression of Npt2c. Am J Physiol Renal Physiol 285:F1271-8 DOI Electronic Resource Number

57. Verri T, Markovich, D, Perego, C, Norbis, F, Stange, G, Sorribas, V, Biber, J, Murer, $\mathrm{H}$ (1995) Cloning of a rabbit renal Na-Pi cotransporter, which is regulated by dietary phosphate. Am J Physiol 268:F626-33 DOI Electronic Resource Number

58. Vervloet MG, van Ittersum FJ, Buttler RM, Heijboer AC, Blankenstein MA, ter Wee PM (2011) Effects of dietary phosphate and calcium intake on fibroblast growth factor-23. Clin J Am Soc Nephrol 6:383-9 DOI Electronic Resource Number

59. Villa-Bellosta R, Ravera S, Sorribas V, Stange G, Levi M, Murer H, Biber J, Forster IC (2009) The Na+-Pi cotransporter PiT-2 (SLC20A2) is expressed in the apical membrane of rat renal proximal tubules and regulated by dietary $\mathrm{Pi}$. Am J Physiol Renal Physiol 296:F691-9 DOI Electronic Resource Number 
60. Virkki LV, Biber J, Murer H, Forster IC (2007) Phosphate transporters: a tale of two solute carrier families. Am J Physiol Renal Physiol 293:F643-54 DOI Electronic Resource Number

61. Weinman EJ, Biswas R, Steplock D, Wang P, Lau YS, Desir GV, Shenolikar S (2011) Increased renal dopamine and acute renal adaptation to a high-phosphate diet. Am J Physiol Renal Physiol 300:F1123-9 DOI Electronic Resource Number

62. Woda C, Mulroney SE, Halaihel N, Sun L, Wilson PV, Levi M, Haramati A (2001) Renal tubular sites of increased phosphate transport and $\mathrm{NaPi}-2$ expression in the juvenile rat. Am J Physiol Regul Integr Comp Physiol 280:R1524-33 DOI Electronic Resource Number 